\title{
ESTIMACIÓN DE CONTAMINACIÓN POR PLAGUICIDAS CON INDICADORES AMBIENTALES Y ECONÓMICOS EN HUERTAS DE TOMATE EN SANTA FE
}

\author{
Castignani, M. I. ${ }^{1}$; Arregul, M. C. ${ }^{1}$ \& Pelatti, n. S. ${ }^{1}$
}

\begin{abstract}
RESUMEN
En el cinturón hortícola santafesino se emplean plaguicidas con aplicaciones frecuentes y elevadas dosis aumentando costos y contaminación. El objetivo del trabajo fue cuantificar el impacto económico de producir con tres niveles de riesgo de contaminación por plaguicidas en tomate.

A partir de encuestas discriminando la tecnología empleada en el uso de plaguicidas se determinaron tres tipologías: Alto (más de 60 tratamientos por ciclo), Medio (entre 40 y 60) y Bajo riesgo de contaminación (menos de 40). Para cada una se evaluó el riesgo con un indicador de lógica difusa y el costo de la contaminación por diferencia de margen bruto entre tipologías.

Se observó que con alto riesgo de contaminación se produjo 22 y $33 \%$ más que con medio y bajo. Un menor riesgo disminuyó en 35\% el margen bruto por lo que aplicar tecnologías de bajo impacto ambiental no resultó conveniente en términos económicos.
\end{abstract}

Palabras clave: riesgo ambiental, evaluación económica, lógica difusa, horticultura.

\section{SUMMARY}

\section{Pesticide contamination assessment with environmental and economic indicators in Santa Fe tomato farms.}

In Santa Fe horticultural belt, pesticides are sprayed frequently and with high active ingredient doses giving higher production costs and contamination levels. The aim of this study was assessing the economic impact of producing tomato with three pesticide risk contamination levels.

Three farm types were determined by means of surveys taking account technology and pesticides use: High (more than 60 applications during crop cycle); Medium (40 to 60 applications) and Low (less than 40 treatments) level of pesticide contamination risk. Pesticide contamination risk was calculated with a fuzzy logic indicator and economic costs were assessed by gross margin differences among farm typologies.

Crop production with high contamination risk was 22 and $33 \%$ higher than with medium and low level, respectively. Gross margin was 35\% lower in farms with less contamination risks. Therefore, technology with low environmental impact was not economically sustainable.

Key words: environmental risk, economic assessment, fuzzy logic, horticulture.

1.- Facultad de Ciencias Agrarias, Universidad Nacional del Litoral. Kreder 2805. (3080) Esperanza, provincia de Santa Fe. E-mail: mcastign@fca.unl.edu.ar

Manuscrito recibido el 29 de junio de 2004 y aceptado para su publicación el 17 de diciembre de 2004. 